\title{
Kortárs egészségfejlesztési programok közvetlen hatása alsó tagozatos gyermekek kézhigiénés tudására és megfelelő kézmosási technikájára
}

\author{
Lehotsky Ákos dr. ${ }^{1,2}$. Falus András dr. ${ }^{3,4}$ - Lukács Ágnes dr. ${ }^{5}$ \\ Füzi Andrea Rita dr. ${ }^{6}$. Gradvohl Edina dr. ${ }^{5}$ \\ Mészárosné Darvay Sarolta dr. ${ }^{7}$ - Bihariné Krekó Ilona ${ }^{7}$ \\ Berta Kata ${ }^{5}$ - Deák Alexandra ${ }^{5}$ - Feith Helga Judit dr. ${ }^{5}$ \\ ${ }^{1}$ HandInScan Zrt., Debrecen \\ ${ }^{2}$ Országos Onkológiai Intézet, Higiénés Csoport, Budapest \\ ${ }^{3}$ Semmelweis Egyetem, Általános Orvostudományi Kar, Genetikai, Sejt- és Immunbiológiai Intézet, Budapest \\ ${ }^{4}$ EDUVITAL Alapítvány, Budapest \\ ${ }^{5}$ Semmelweis Egyetem, Egészségtudományi Kar, Alapozó Egészségtudományi Intézet, \\ Társadalomtudományi Tanszék, Budapest \\ ${ }^{6}$ Budapest Főváros Kormányhivatal II. kerületi Hivatala, Népegészségügyi Osztály, Budapest \\ ${ }^{7}$ ELTE Tanító- és Óvóképző Kar, Természettudományi Tanszék, Budapest
}

\begin{abstract}
Bevezetés és célkitüzés: Budapesti alsó tagozatos gyermekek $(\mathrm{n}=165)$ kézhigiénére vonatkozó ismereteit vizsgáltuk. A kutatás célja: kisiskolások körében új pedagógiai eljárás, a kortársoktatás alkalmazása és optimalizálása a megfeleló kézhigiénia kialakításában.

Módszer: A gyermekek szociális helyzetét és előzetes tudását bemeneti kérdőívek kitöltésével egyetemisták mérték fel. A tudásra vonatkozó felmérést négy- $(\mathrm{n}=85)$ és nyolcórás $(\mathrm{n}=36)$ oktatás után is elvégeztük. Emellett a kézmosás helyes gyakorlatának hatékonyságát Semmelweis Scanner segítségével teszteltük közvetlenül a kéz fluoreszkáló krémmel való bedörzsölése után, a négy- és nyolcórás oktatás előtt $(\mathrm{n}=166)$ és után $(\mathrm{n}=74 ; \mathrm{n}=35)$ is.

Eredmények: A kézhigiénére vonatkozó tudás a bemeneti felméréshez képest szignifikánsan nőtt a kortársoktatási program után, a négy- és a nyolcórás képzést követően. A kisebb gyermekeknél a nyolcórás képzés hatása kifejezettebb volt. Hasonló eredményeket kaptunk a kéz felszínének bedörzsölése után a kimaradó területek számának változásában is.

Köpetkeztetés: A kézhigiéniai tudásra vonatkozó szociológiai felmérések és a közvetlen fizikai mérések egyaránt arra utalnak, hogy a megfelelő pedagógiai eljárásokkal elvégzett képzés eredményes, és hozzájárul a 6-10 éves gyermekek környezettudatos higiéniai kultúrájának kialakításához, átalakításához.
\end{abstract}

Orv Hetil. 2018; 159(12): 485-490.

Kulcsszavak: kézhigiéné, iskolai egészségfejlesztés, kortársoktatás, a program hatékonyságának mérése

Direct effect of contemporary health education programmes on the knowledge about hand hygiene and technique of hand washing in primary school age children

Introduction and aim: In the case of primary school children in Budapest $(\mathrm{n}=165)$, data on their social status and their previous knowledge on hand hygiene were elicited with the help of pre-knowledge questionnaires issued by students of higher education. The aim of the research was introducing a novel pedagogical procedure - application and optimization of peer education in the development of proper hand hygiene among primary school students. 
Method: The knowledge-based survey was conducted after four $(\mathrm{n}=85)$ and eight hours of teaching $(\mathrm{n}=36)$. In addition, the effectiveness of hand washing was tested immediately before $(\mathrm{n}=166)$ and after the four $(\mathrm{n}=74)$ and eight hours of teaching $(\mathrm{n}=35)$ with Semmelweis Scanner after rubbing the hand with fluorescent cream.

Results: Prior knowledge of hand hygiene significantly increased after the four-hour and eight-hour trainings. In the case of smaller children, the effect of the eight-hour training was more pronounced. Similar results were obtained with regards to the changes in the number of areas missed while rubbing the surface of the hand as a result of the teaching.

Conclusion: Sociological surveys on hand hygiene knowledge and direct physical measurements indicate that training with appropriate pedagogical procedures is effective and contributes to the environmentally conscious hygiene culture of children aged 6 to 10 .

Keywords: hand hygiene, school health promotion, peer education, measuring effectiveness of programme

Lehotsky Á, Falus A, Lukács Á, Füzi AR, Gradvohl E, Mészárosné Darvay S, Bihariné Krekó I, Berta K, Deák A, Feith HJ. [Direct effect of contemporary health education programmes on the knowledge about hand hygiene and technique of hand washing in primary school age children]. Orv Hetil. 2018; 159(12): 485-490.

(Beérkezett: 2017. december 21.; elfogadva: 2018. január 19.)

\section{Rövidítések}

ETT-TUKEB = Egészségügyi Tudományos Tanács, Tudományos és Kutatásetikai Bizottság; HBSC $=($ Health Behaviour in School-aged Children) az iskoláskorú gyermekek egészségmagatartása elnevezésű, a WHO-val együttmúködésben megvalósuló nemzetközi kutatás; TANTUdSZ = Tanulj, tanitsd, tudd! Ifjúsági Egészségnevelési Program; UV = ultraviola, 'ibolyántúli'; WHO = (World Health Organization) Egészségügyi Világszervezet

A magyar lakosság egészségi állapota nemzetközi összehasonlításban évtizedek óta kiemelkedően rossz. A halandósági viszonyokat jellemző, születéskor várható átlagos élettartamok kedvezőtlenebbek, mint ami az ország gazdasági potenciálja alapján várható volna.

A valós és hosszú távú megoldásoknak alapvetően fontos tényezője az ifjúság egészségtudatos nevelése a legfiatalabb életkortól kezdve. A higiéniai nevelés egyik leggyakorlatibb mozzanata a kézmosás megfelelő módon történő bemutatása és begyakoroltatása. A mindennapi életben elvárható kézmosási technika mellett a kórházi fertőzések megelőzése az egészségügyi minőségbiztosításnak és a betegbiztonságnak az egyik pillére, amelynek nemcsak hatékony, hanem költséghatékony eszköze is a megfelelő kézhigiéné $[1,2]$. A rendelkezésre álló megoldások közül, amelyek a kézhigiénés magatartást javíthatják [3-5], a leghatékonyabbnak az automatizált, direkt ellenőrzés és az azonnali, vizuális visszacsatolás tünik.

A kisiskolások fogékonyabbak a fertőzésekkel szemben, amit részben a fejlődő, még nem teljesen érett immunrendszer, részben a korosztályra jellemző viselkedési normák magyaráznak [6]. A 6-10 éves korosztály számára még nem egyértelmű a zsebkendő használatának vagy a kézmosás szerepének fontossága a szennyezett tárgyak (például játék, kapaszkodók, nyilvános mellékhelyiségek) érintése utáni fertőzések elkerülésében. A fer- tőzések következménye túlmutat az egyénen, hiszen az iskolai közösségekben a diákok hiányzása visszahat az egész osztályra. Emellett a tanár számára többlet-erőfeszítést jelent a hiányzó diák segítése a felzárkózásban, a szülő számára pedig a munkából való hiányzás okoz megoldandó feladatot [7]. A fertőzések visszaszorításának leghatékonyabb, legegyszerúbb és legolcsóbb eszköze a megelőzés, amelynek egyik komponensét a megfelelő kézhigiénés technika elsajátítása jelenti [1]. Ez a megállapítás Semmelweis Ignác (1818-1865) legfontosabb hagyatéka.

Többek között ezt a célt követve alakítottuk ki a Tanulj, tanitsd, tudd! (TANTUdSZ) Ifjúsági Egészségnevelési Programot, amelynek legfontosabb célkitűzése egy hatékony, innovatív iskolai ismeretátadási pedagógiai módszer kidolgozása és hosszú távú fenntarthatósága kortársoktatás keretében [8]. Ennek része a kézhigiéniai program is.

Jelen munkánkban a kisiskolások kézhigiéniai ismereteiről és oktatásuk hatékonyságának eredményeiről számolunk be.

\section{Módszer}

A TANTUdSZ kézhigiéniai oktatási program eredményességét újonnan kidolgozott, önkitöltős kérdőívvel és annak kiértékelésével, valamint speciális, fluoreszcens anyagot tartalmazó kézápoló tesztkrémmel bedörzsölt kézről UV-A sugárzásban készült digitális felvétel kiértékelésével mértük.

A kvantitatív szociológiai módszer során alkalmazott kérdőívben saját szerkesztésû kérdéseket alkalmaztunk. A szükséges előzetes engedély beszerzését követően a kérdőívek nemzetközi minőség-ellenőrzéssel validált (HBSC; WHO, 2002) és nem validált kérdéseket egyaránt tartalmaztak. Az alapvető szociodemográfiai változók (nem, életkor, együtt élő testvérek száma, a család 
gazdasági státusza, önbevallás alapján történő egészségi állapot, valamint tanulmányi eredmény) mellett a helyes kézmosásra vonatkozóan tudást, egészségmagatartást és attitüdöt is mértünk.

Jelen közleményben a kérdőíves felmérés tudásra vonatkozó kérdéseit elemezzük. A tudásdimenzióban mértük az optimális kézmosás másodpercben megadott hoszszát, a legjobb kézszárítási módot (zárt kérdésként egy jó válasszal), valamint a legjobb kéztisztasági szert a mindennapos kézmosáshoz (zárt kérdésként egy jó válasszal).

A bedörzsölés minőségének vizsgálatára Semmelweis Scannert (HandInScan Zrt. Debrecen), egy digitális képfeldolgozást alkalmazó berendezést alkalmaztunk, amely képes a kézhigiénés technika (tökéletes kézmosás) mérésére [9]. A mérés során UV-A sugárzás által megvilágított környezetben képet készítettünk a speciális adalékot tartalmazó kézkrémmel bedörzsölt kézről. A mérésben részt vevők visszajelzést nem kaptak az elért eredményról, a készüléknek ezt a funkcióját kikapcsoltuk, így az „öntanítás” [10], a kutatás ezen szakaszában, még nem befolyásolta a következő mérés eredményét. A mérések után a készülék által készített és digitálisan tárolt felvételeket értékeltük ki retrospektíven. Mindkét kéz felszínét 10-10 régióra osztottuk, mind a tenyér, mind a kézhát oldalán (így összesen 40 régióra). Az ujjak egy-egy régiót képviseltek, az ujjvégek külön egységes régióba kerültek. Ezt a megoldást a jelen felmérést megelőző időszakban kapott eredmények [11] alapján választottuk annak érdekében, hogy az adatokat minél célravezetőbben alkalmazhassuk. A kiértékelés során elsősorban a bedörzsöléskor kimaradó területeket vizsgáltuk. Az UV sugárzásban a bedörzsölésből kimaradó régió sötétebb foltként jelent meg. Ha egy régióban „foltot”, vagyis „nem vagy nem megfelelően bedörzsölt” területet találtunk, akkor a régiót „hibaként” rögzítettük. Ezzel a módszerrel a kézháton vagy a tenyéren maximálisan 10 hibát számolhattunk össze. A hiba elhelyezkedése alapján az eredményekből Excel-táblázatot készítettünk, amelyből a statisztikai elemzést végeztük.

A TANTUdSZ 4, illetve 8 tanórás kézhigiéniai kortársoktatási programot egészségtudományi és pedagógusképző felsőoktatási intézmények hallgatói, valamint középiskolás diákok tartották 2017 tavaszán fővárosi, budai általános (6-10 éves) és középiskolai (14-18 éves) diákok részére. Jelen közleményben a kisiskolások körében tartott kortársoktatási programban részt vevők $(\mathrm{n}=85)$, valamint a kontrollcsoport $(\mathrm{n}=81)$ adatait elemezzük (1. táblázat). A 4 tanórás programban 49 , míg a 8 tanórás programban 36 alsó tagozatos (1-3. osztályos) diák vett részt.

A kézhigiéniai oktatási programban részt vevő kisiskolások átlagos életkora 8,1 életév volt; 57,7\%-uk lány, míg 42,3\%-uk fiú volt. A válaszadóval együtt élő testvérek átlagos száma 1,39 volt, a legtöbben $(46,7 \%)$ egy testvérrel, 24,0\%-uk két testvérrel élt együtt. A válaszadók nagyobb hányadának családjában legalább 3 mobiltelefon (74,0\%), 3 vagy több számítógép $(53,2 \%)$, legalább két
1. táblázat $\mid$ A kvantitatív társadalomtudományi és a fizikai mérésben részt vevők száma (fő)

\begin{tabular}{lccc}
\hline & $\begin{array}{c}\text { Intervenció } \\
\text { elótt }\end{array}$ & $\begin{array}{c}\text { Négy tanórát } \\
\text { követően }\end{array}$ & $\begin{array}{c}\text { Nyolc tanórát } \\
\text { követően }\end{array}$ \\
\hline $\begin{array}{l}\text { A kérdő́ivet kitöltők } \\
\text { száma }\end{array}$ & 165 & 85 & 36 \\
$\begin{array}{l}\text { A kézszkennelések } \\
\text { száma }\end{array}$ & 166 & 74 & 35 \\
\hline
\end{tabular}

személygépkocsi $(61,3 \%)$ és legalább két fürdőszoba $(61,0 \%)$ volt a lekérdezéskor. A többség jó tanulónak tartotta magát $(28,2 \%$ a legjobb tanulók közé, míg $41,2 \%$ inkább a jobb tanulók közé sorolta magát). A diákok több mint kétharmada $(68,8 \%)$ kiválónak minősítette egészségi állapotát a hasonló korú gyermekekéhez képest, 26,0\% jónak, 5,2\% elfogadhatónak, s mindössze 2 fö $(2,6 \%)$ minősítette egészségi állapotát rossznak.

A papíralapú kérdőíveknek, valamint a kézszkennelés adatainak az elemzése az adattisztítást követően az SPSS statisztikai program 22-es verziójával történt.

A kutatás a megfelelő beleegyező szülői nyilatkozatokat tartalmazó ETT-TUKEB-engedély (ETT-TUKEB No. 18240-2/2017/EKU) alapján került kivitelezésre.

\section{Eredmények}

A programban részt vevő kisiskolások mindegyike helyesen tudta, hogy a kézmosáshoz nélkülözhetetlen a szappan és a víz.

Az intervenció előtt a válaszadó kisdiákok túlnyomó többsége $(74,7 \%)$ helytelenül a fertőtlenítő hatású szappan használatát, 2,7\%-uk pedig a tömbszappant jelölte meg a mindennapi kézmosáshoz, és csak 22,7\%-uk adott helyes választ, vagyis hogy a rendszeres kézmosáshoz elegendő a folyékony szappan használata is. A helyes választ adók aránya mind a 4 , mind a 8 tanórás egészségfejlesztési programot követően meredeken emelkedett (1.ábra).

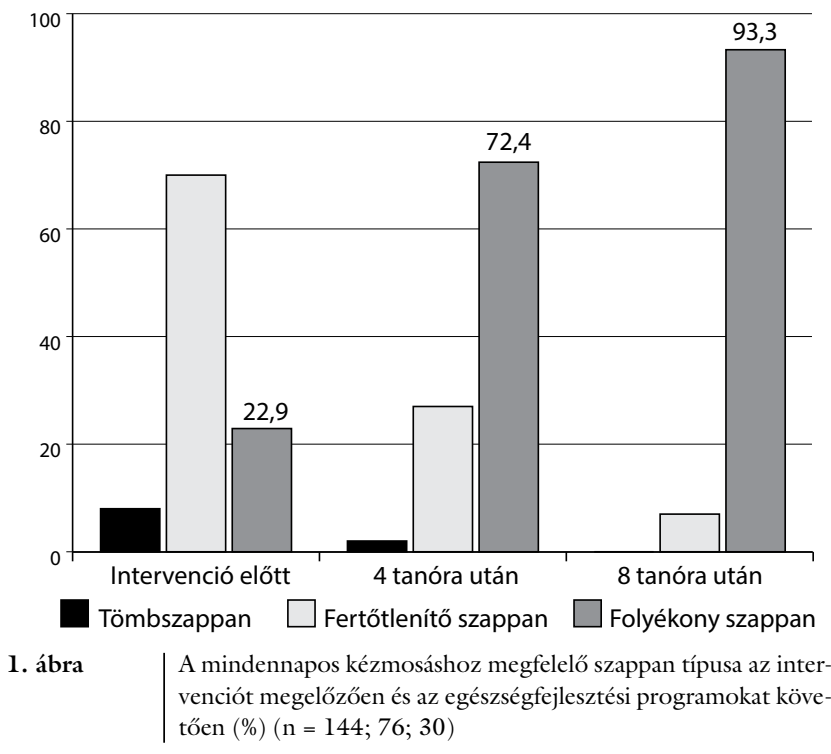


Nagyon erős statisztikai összefüggést találtunk a 4 tanórás $(\mathrm{p}<0,001)$ és a 8 tanórás $(\mathrm{p}=0,014)$ program után az erre a kérdésre adott válaszok és a kérdezett évfolyama között. A nagyon egyértelmű tudásnövekedés ellenére az első osztályos kisdiákok mind a 4 , mind a 8 tanórás programot követően kisebb hányadban válaszoltak jól erre a kérdésre. Ugyanakkor nem befolyásolta az intervenció előtt és az egészségfejlesztési programokat követően erre a kérdésre adott válaszokat a diákok neme, valamint az, hogy milyen tanulónak tartotta magát a kérdezett.

Felmérésünkben vizsgáltuk azt is, hogy a diákok szerint mennyi ideig kell kezet mosni. Eredményeink szerint az egészségfejlesztési program hatására a helytelen értékeket adók száma, az átlag és a standard deviáció értékei is csökkentek (2. táblázat).

Az intervenció előtt a programban részt vevők 39,5\%-a úgy vélte, hogy kevesebb, mint 20 másodperc elegendő a helyes kézmosáshoz, 19,6\%-uk pedig úgy, hogy több, mint 30 másodpercig kell kezet mosni - vagyis a többség $(59,1 \%)$ helytelenül tudta az erre a kérdésre adandó helyes választ. A 4 tanórás intervenció után már csak 2,6\% mondta azt, hogy kevesebb, mint 20 másodperc elegendő, és 14,3\%-uk jelölte be, hogy 30 másodpercnél több idő kell, vagyis a helyes választ adók aránya már $83,1 \%$ volt. A 8 tanórás intervenció után pedig a helyes válaszok aránya tovább emelkedett, $87,5 \%$-ra. Ennél a kérdésnél is megállapítható, hogy a kérdezett neme és az, hogy milyen tanulónak tartotta magát, nem befolyásolta az eredményeket. Ugyanakkor itt is nagyon erôs statisztikai öszszefüggést találtunk a 4 tanórás $(\mathrm{p}<0,001)$ és a 8 tanórás $(\mathrm{p}=0,022)$ program után az erre a kérdésre adott válaszok és a kérdezett évfolyama között: az első osztályos kisdiákok mind a 4 , mind a 8 tanórás programot követően kisebb hányadban válaszoltak jól erre a kérdésre.

Ugyancsak helytelen választ adott a többség az intervenció előtt a kéz tisztasága szempontjából legmegfelelőbb kéztörlési módra, ugyanis mindössze 16,0\% tudta helyesen, hogy a használat után eldobandó papírtörlő a legmegfelelőbb. A válaszadók $61,3 \%$-a a textiltörülközőt, míg 22,7\%-uk a falra szerelhető elektromos kézszárítót jelölte meg. A 4 tanórás intervenció után már 75,3\% adott helyes választ, de még mindig előfordult a textilből készült törülköző $(23,4 \%)$, valamint a falra szerelhető elektromos kézszárító (1,3\%) válaszként. A 8 tanórás intervenció után 90,6\% helyesen válaszolt erre a kérdésre. Az egészségfejlesztési program hatására bekövetkező tudásnövekedés itt is egyértelmú, és ebben az esetben is erős statisztikai összefüggést $(\mathrm{p}=0,009)$ találtunk a 4 tanórás programot követően a kérdésre adott helyes válaszok és az évfolyam között. Ugyanakkor a 8 tanórás program után már nincs statisztikailag is alátámasztható különbség a helyes kéztörlési mód és az évfolyam között $(\mathrm{p}=0,124)$, annak ellenére, hogy ebben az esetben is több első osztályos adott helytelen választ.

A program hatását a gyakorlati kézhigiénés magatartásra a kéz felszínének bedörzsölése során kimaradó te- rületek számának változásán keresztül vizsgáltuk. Az elméleti oktatás előtti héten kezdtük meg a méréseket 166 kisiskolás részvételével. A következő mérésben már csak a 4 és 8 órás képzésben részesülő diákok vettek részt, a 3. mérésen pedig már csak a 8 órás oktatásban részt vevők. A 3. táblázatban összefoglalt eredmények jól tükrözik a program célját, hiszen az elméleti tudás mellett az iskolások kézhigiénés gyakorlata is javult a képzés során. Míg a program előtt a bevont iskolásoknál átlagosan 6 terület maradt ki a megfelelő bedörzsölésből, addig ez az eredmény a 4 órás képzés után 3,25 területre mérséklődött, mely érték a 8 órás képzés után még tovább csökkent. A kiértékelés során vizsgáltuk a kimaradó területek elhelyezkedését a kéz felszínén. A TANTUdSZ egészségfejlesztési program hatása - az egészségügyi dolgozókra

\begin{tabular}{|c|c|c|c|c|}
\hline \multirow[t]{2}{*}{ 2. táblázat } & \multicolumn{4}{|c|}{$\begin{array}{l}\text { A kézmosás hosszára (másodperc) adott válaszok leíró statiszti- } \\
\text { kai értékei }\end{array}$} \\
\hline & & $\begin{array}{l}\text { Intervenció } \\
\text { elött }(n=146)\end{array}$ & $\begin{array}{l}\text { Négy tanóra } \\
\text { után }(\mathrm{n}=76)\end{array}$ & $\begin{array}{l}\text { Nyolc tanóra } \\
\text { után }(\mathrm{n}=31)\end{array}$ \\
\hline Minimum & & 1 & 5 & 10 \\
\hline Maximum & & 180 & 120 & 100 \\
\hline Átlag & & 26,9 & 26,5 & 25,8 \\
\hline Standard de & iiáció & 26,7 & 18,1 & 17,2 \\
\hline
\end{tabular}

3. táblázat |A szkennelés mérési eredményeinek összefoglalása

\begin{tabular}{|c|c|c|c|c|}
\hline \multirow{2}{*}{\multicolumn{2}{|c|}{$\begin{array}{l}\text { A résztvevők száma } \\
\text { (fó) }\end{array}$}} & 1. mérés & 2. mérés & 3. mérés \\
\hline & & 166 & 74 & 32 \\
\hline \multirow[t]{3}{*}{$\begin{array}{l}\text { Jobb } \\
\text { tenyér }\end{array}$} & $\begin{array}{l}\text { A kimaradó területek } \\
\text { száma }\end{array}$ & 5 & 0 & 0 \\
\hline & A hibázók száma & 3 & 0 & 0 \\
\hline & A hibázók aránya (\%) & 2 & 0 & 0 \\
\hline \multirow[t]{3}{*}{$\begin{array}{l}\text { Jobb } \\
\text { kézhát }\end{array}$} & $\begin{array}{l}\text { A kimaradó területek } \\
\text { száma }\end{array}$ & 562 & 131 & 46 \\
\hline & A hibázók száma & 140 & 57 & 23 \\
\hline & A hibázók aránya (\%) & 84 & 77 & 72 \\
\hline \multirow[t]{3}{*}{$\begin{array}{l}\text { Bal } \\
\text { tenyér }\end{array}$} & $\begin{array}{l}\text { A kimaradó területek } \\
\text { száma }\end{array}$ & 11 & 1 & 0 \\
\hline & A hibázók száma & 6 & 1 & 0 \\
\hline & A hibázók aránya (\%) & 4 & 1 & 0 \\
\hline \multirow[t]{3}{*}{$\begin{array}{l}\text { Bal } \\
\text { kézhát }\end{array}$} & $\begin{array}{l}\text { A kimaradó területek } \\
\text { száma }\end{array}$ & 429 & 109 & 40 \\
\hline & A hibázók száma & 133 & 51 & 19 \\
\hline & A hibázók aránya (\%) & 80 & 69 & 59 \\
\hline \multicolumn{2}{|c|}{ Összes hiba } & 1007 & 241 & 86 \\
\hline \multicolumn{2}{|c|}{ Szórás (standard deviáció, SD) } & 6,479 & 3,132 & 2,811 \\
\hline \multicolumn{2}{|c|}{ Standard hiba (standard error, SE) } & 0,503 & 0,364 & 0,49 \\
\hline \multicolumn{2}{|c|}{ Konfidenciaintervallum (CI) (95\%) } & $\begin{array}{c}5,081- \\
7,052\end{array}$ & $\begin{array}{c}2,543- \\
3,970\end{array}$ & $\begin{array}{c}1,752- \\
3,562\end{array}$ \\
\hline \multicolumn{2}{|c|}{ Átlagos hibaszám } & 6,0663 & 3,2568 & 2,6875 \\
\hline
\end{tabular}


fókuszáló felmérés során tapasztaltakhoz hasonlóan [9] - a tenyér csaknem tökéletes bedörzsölését mutatta. A kutatásban a kérdezettek domináns kezére is rákérdeztünk, amelynek aránya megfelelt a populációkban a jobbkezesek általánosan várható arányának [12], 90\%nak. A jobb kézháton hibázók nagyobb arányának magyarázata az lehet, hogy a domináns kézzel a másik kézen precízebben, koordináltabban tudunk mozdulatokat kivitelezni.

\section{Megbeszélés}

A TANTUdSZ program a kortársoktatásnak az innovatív, korosztály-specifikus, játékos, a frontális oktatást kerülő módszertanára épül. A kortársoktatás módszere az egészségfejlesztési programok tekintetében nemzetközi szinten igen népszerü, hatékonysága számos pszichológiai és szociológiai elmélettel magyarázható [13-15]. Ugyanakkor nemcsak a célpopuláció, hanem a kortársoktató számára is előnyös, hiszen közben fejlődik a tudása, a szociális attitűdje és a személyisége [14, 16-18].

Komplex felmérésünk számos fontos tanulsággal zárult. Bár a mintába bekerült gyermekek a magyar átlaghoz képest jóval kedvezőbb társadalmi státuszú, így optimálisabb egészségmagatartású családokban nevelkednek [19], eredményeink azt mutatják, hogy az egészségfejlesztési programot megelőzően a többségnek sem a kézhigiénés tudása, sem az alkalmazott kézmosási módszere nem volt kielégítő.

Eredményeink szerint a kortársoktatás játékos programja, valamint a megtanított kéztisztítási mozdulatok, amelyek a WHO „6 lépéses protokollján” [20] alapulnak, egyértelmúen elősegítik a diákok kézhigiénés technikájának fejlődését.

A 4 versus 8 tanórás program hatékonyságának kérdésében megállapítható, hogy a kisiskolások körében még a plusz 4 tanórás (vagyis összesen 8 tanórás) kézmosási program is eredményezett javulást mind a tudásban, mind a kézmosási technikában. Ugyanakkor az elsó osztályosok, valamint a másodikos, harmadikos kisiskolások között jelentős a különbség, hiszen az éppen iskolát kezdő kisiskolásoknál a hosszabb (8 tanórás) egészségfejlesztési program különösen fontos volt, mert a 4. tanórát követő plusz 4 tanórás program tovább segítette a kézhigiénés tudásszint növekedését. A 4, illetve a 8 tanórás program hatása közötti különbség a második és harmadik osztályosok között azonban már nem jelenik meg statisztikailag bizonyítható mértékben.

\section{Következtetés}

Meglepő módon a programban részt vevő gyermekek neme és önbevalláson alapuló iskolai előmenetele nem mutatott összefüggést egyetlen változóval sem.

Eredményeink egyértelmüen arra ösztönzik a kutatócsoportot, hogy kutatásunkat, ezen belül is a helyes kéz- mosásra való nevelést kiterjesszük más társadalmi státuszú, illetve tanulási nehézséggel, magatartási zavarral küzdő gyermekek csoportjaira is.

Anyagi támogatás: A kutatás a Magyar Tudományos Akadémia támogatásával, a Tantárgy-pedagógiai Kutatási Program keretein belül valósult meg.

Szerzôi munkamegosztás: Le. Á.: Szkennelés, adatgyưjtés, az adatok elemzése, a publikáció megírása. F. A.: Az adatok értékelése, a publikáció megírása. Lu. Á.: Szakirodalom, adattisztítás, az elemzési módszertan kidolgozása, a publikáció ellenőrzése, kiegészítése. F. A. R.: A publikáció ellenőrzése, kiegészítése. G. E.: A publikáció ellenőrzése, kiegészítése. M. D. S.: A publikáció ellenőrzése, kiegészítése. B. K. I.: A publikáció ellenőrzése, kiegészítése. B. K.: Az adatok bevitele, szakirodalom. D. A.: Az adatok bevitele, szakirodalom. F. H. J.: A kérdőíves adatok elemzése, a munka összehangolása és szervezése, a publikáció megírása, véglegesítése. A cikk végleges változatát valamennyi szerző elolvasta és jóváhagyta.

Érdekeltségek: Lehotsky Ákos a HandInScan Zrt. társalapítója.

\section{Köszönetnyilvánítás}

Köszönetünket fejezzük ki a HandInScan Zrt.-nek és az Ecolab-Hygiene Kft.-nek a kutatáshoz szükséges eszközök támogatásáért, valamint a TANTUdSZ Munkacsoport további tagjainak: Horváth Zsoltnak, Karacs Zsuzsannának, Kitzinger Istvánnak, dr. Kolosai Neddának, Körösi Molnár Andreának, Kukovecz Györgynének, Melicher Dórának, Nagyné Horváth Emíliának, Soósné dr. habil. Kiss Zsuzsannának, Suhajdáné dr. Urbán Veronikának, Réfi Ritának, Szalainé Tóth Tündének, Zombori Juditnak, valamint a Semmelweis Egyetem Egészségtudományi Kara tudományos diákköri munkát végző hallgatóinak: Ábrám Borókának, Lovas Krisztinának és Szőke Andreának.

\section{Irodalom}

[1] Pittet D, Boyce JM. Hand hygiene and patient care: pursuing the Semmelweis legacy. Lancet Infect Dis. 2001; 1(Suppl 1): 9-20.

[2] Mayer J, Mooney B, Gundlapalli A, et al. Dissemination and sustainability of a hospital-wide hand hygiene program emphasizing positive reinforcement. Infect Control Hosp Epidemiol. 2011; 32: 59-66

[3] Reilly JS, Price L, Lang S, et al. A pragmatic randomized controlled trial of 6-step vs 3-step hand hygiene technique in acute hospital care in the United Kingdom. Infect Control Hosp Epidemiol. 2016; 37: 661-666.

[4] Chen LF, Carriker C, Staheli R, et al. Observing and improving hand hygiene compliance: implementation and refinement of an electronic-assisted direct-observer hand hygiene audit program. Infect Control Hosp Epidemiol. 2013; 34: 207-210.

[5] Boyce M. Measuring healthcare worker hand hygiene activity: current practices and emerging technologies. Infect Control Hosp Epidemiol. 2011; 32: 1016-1028.

[6] Randle J, Metcalfe H, Webb JCA, et al. Impact of an educational intervention upon the hand hygiene compliance of children. J Hosp Infect. 2013; 85: 220-225. 
[7] Wang Z, Lapinski M, Quilliam E, et al. The effect of hand-hygiene interventions on infectious disease-associated absenteeism in elementary schools: A systematic literature review. Am J Infect Control 2017; 45: 682-689.

[8] Feith HJ, Melicher D, Falus A. Instead of an afterword, about the TANTUdSZ program. In: Falus A, Melicher D. (eds.) Colourful health awareness - Understand it, do it. like it! [Utószó helyett a TANTUdSZ programról. In: Falus A, Melicher D. (szerk.) Sokszínú egészségtudatosság - Értsd, csináld, szeresd] SpringMed Kiadó, Budapest, 2015; pp. 293-297. [Hungarian]

[9] Lehotsky A, Morvai J, Szilágyi L, et al. Hand hygiene technique assessment using electronic equipment in 26 Hungarian healthcare institutes. [A kézhigiénés technika vizsgálata elektronikus ellenőrző berendezés segítségével 26 magyarországi betegellátó intézményben.] Orv Hetil. 2017; 158: 1143-1148. [Hungarian]

[10] Lehotsky A, Szilágyi L, Ferenci T, et al. Quantitative impact of direct, personal feedback on hand hygiene technique. J Hosp Infect. 2015; 91: 81-84.

[11] Szilágyi HT, Lehotsky A, Nagy M, et al. A large-scale assessment of hand hygiene quality and the effectiveness of the "WHO 6-steps". BMC Infect Dis. 2013; 13: 54-63.

[12] Hardyck C, Petrinovich LF. Left-handedness. Psychol Bull. 1977; 84: 385-404.

[13] Sloane BC, Zimmer CG. The power of peer health education. J Am Coll Health 1993; 41: 241-245.

[14] Milburn K. A critical review of peer education with young people with special reference to sexual health. Health Educ Res. 1995; 10: $407-420$.
[15] Turner G, Shepherd J. A method in search of a theory: peer education and health promotion. Health Educ Res. 1999; 14: 235247.

[16] Klein NA, Sondag KA, Drolet JC. Understanding volunteer peer health educators' motivations: applying social learning theory. J Am Coll Health 1994; 43: 126-130.

[17] Sawyer RG, Pinciaro P, Bedwell D. How peer education changed peer sexuality educators' self esteem, personal development, and sexual behaviour. J Am Coll Health 1997; 45: 211-217.

[18] Parkin S, McKeganey N. The rise and rise of peer education approaches. Drugs Educ Prev Policy 2000; 7: 293-310.

[19] Németh Á, Költő A. (eds.) Health Behaviour in School-aged Children (HBSC): A WHO-collaborative Cross-National Study. National Report, 2014. [Németh Á, Költő A. (szerk.) Egészség és egészségmagatartás iskoláskorban - 2014. Az iskoláskorú gyermekek egészségmagatartása elnevezésű, az Egészségügyi Világszervezettel együttmúködésben megvalósuló nemzetközi kutatás 2014. évi felmérésérôl készült nemzeti jelentés.] Nemzeti Egészségfejlesztési Intézet, Budapest, 2016. [Hungarian]

[20] World Health Organization. Hand Hygiene: Why, How \& When? WHO, Geneva, revised August 2009. Available from: http://www.who.int/gpsc/5may/Hand_Hygiene_Why_How_ and_When_Brochure.pdf

(Falus András dr., Budapest, Nagyvárad tér 4., 1089 e-mail: falus.andras@med.semmelweis-univ.hu) 